\title{
Archaeological Cultures of the Near East and Northern Eurasia In Light of the Indo-European Problem
}

\author{
Grigoriev Stanislav* \\ Institute of History and Archaeology, Russian Academy of Sciences, Russia \\ *Corresponding author: Grigoriev Stanislav, 454080, Lenina-str. 68-10, Chelyabinsk, Russia
}

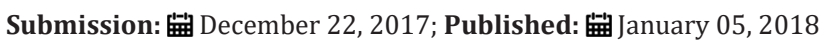

\begin{abstract}
Today the most reliable linguistic reconstruction of the Indo-European Homeland is that suggested by T.V. Gamkrelidze and VV Ivanov. They localized this Homeland in the Near East. From this region it is possible basing on archaeological materials to demonstrate migrations of bearers of Indo-European dialects to the Balkans, the Caucasus, Iran and Central Asia. Earlier it was considered that possibilities to show distribution of the IndoEuropeans from the Near East to Northern Eurasia are absent. However, this popular among archeologists opinion does not correspond to facts. Many authors suggested Near Eastern connections for individual cultures of this region. However, the purest "Near Eastern" complex here is Sintashta culture in the Southern Urals that had formed a basis for formation of many Bronze Age cultures. Contrary to it, the popular today point of view about migration of steppe cultures to Iran and India is not supported by archaeological materials. In addition to this, character of transferred innovations does not allow to speak about cultural borrowings. These innovations were impossible without essential migratory processes, which determined cultural genesis in Northern Eurasia in antiquity, and resulted in distribution of the Indo-European languages.
\end{abstract}

Keywords: Indo-European problem; Archaeology; Northern Eurasia; Near East; Migrations

Abbreviations: BMAC: Bactro-Margianan archaeological complex, PIE: Proto-Indo-European

\section{Introduction}

The place of origins of people speaking Indo-European languages is a very enigmatic problem, important for both archaeology and linguistics. For many years, different areas from Western Europe to India have been discussed in search for this place, and today we have many different hypotheses. However, there is no point to discuss all of them, because in modern science only two are worthy of comment. The best known and most widespread is the hypothesis of the origin of the Indo-Europeans in the steppe zone of Eastern Europe- the so-called "Kurgan theory". VG Childe suggested it as a hypothesis in connection with the Indo-European identity of the 'ochre burials culture' of Eastern Europe; it was supported by S Piggott, and developed subsequently by M Gimbutas, JP Mallory and DW Anthony [1-6].

This approach has many unsolvable archaeological problems [7]. However, Indo-European Homeland localization is, above all, a linguistic problem.

The linguistic aspect of the problem was successfully studied by TV Gamkrelidze and VV Ivanov [8,9], who on the base of protoIndo-European connections with Near Eastern languages, as well as reconstruction of Indo-European environment and economy offered its localization in the Near East. There is no other linguistic reconstruction that can prove convincingly this localization in other areas, except for the presence of proto-Indo-European river-names in Central Europe $[10,11]$. However, the last can be explained by a doubtless migratory character of neolitization of Europe from Anatolia.

Thus, it would be desirable to emphasize two moments: today we have no serious linguistic alternative to the southern localization of the Indo-European Homeland; any linguistic concept must be coordinated with archaeology. The latter caused a bright discussion just after publishing the first works of TV Gamkrelidze and VV Ivanov on this subject.

Some archaeologists suggested archaeological models of the Anatolian [12,13] and Near Eastern [7] Homeland. Nevertheless, at that time the majority of archeologists were supporters of the East European localization of the Homeland. Therefore, a general opinion of archeologists was that there were no cultures having southern origins in Northern Eurasia, but Indo-Iranian movements to the south are visible quite distinctly. Against this background, the articles of N Ya Merpert [14] and EN Chernikh [15] differed. They demonstrated long cultural interplays in the Circumpontic area and conformity of these cultures to the reconstructed PIE language. Finally, they proved the fact that early IE dialects had diffused in the area because of these contacts and connections in the Eneolithic and the Bronze Age. However, it allows us to consider as a Homeland any region round the Black Sea. Therefore, above all it is necessary to be defined with the time and place of formation of a language, which it is possible to consider as Proto-Indo-European (PIE). These questions have been discussed by JP Mallory [16]. 


\section{Time of PIE}

In linguistics at the heart of determination of temporary depth of this or that language a glottochronological method lies. It is supposed that changes in language are rather uniform. Actually it is, of course, a compelled assumption because speed of these changes is caused by concrete social and historical processes, language contacts and a series of other reasons. Therefore, in a real research, chronology of any language is constantly correlated with reconstructed chronology of other languages. As a result, this method cannot be considered as a method of an absolute dating. It is only a relative dating. On the base of the linguistic reconstruction of Gamkrelidze and Ivanov, the stage of the proto-Indo-European language is dated, at the latest, to the 5th- 4th millennia BC [17]. On the base of Grigoriev's archaeological reconstruction, it is dated to the 7th millennium BC [7], but it is necessary to understand that this date is a reconstruction too, instead of any exact measurement.

On the base of statistical methods used in genetic studies Gray and Atkinson dated the initial Indo-European divergence of between 9,800 and 7,800 years BP [18]. The following development of this study resulted in a conclusion that the Indo-European language trees fit with an expansion from Anatolia beginning since 9,500 to 8,000 BP [19].

Possible tie of linguistic chronology with archaeological eras is defined by that in the PIE there is a common term for designation of copper. In this case for the Eastern Europe the best date of the Homeland is the 5th millennium BC when there the first copper objects appeared, and for the Near East it is the 8-7th millennia BC. Respectively, there is a question of legitimacy of the early date for the PIE and of the choice of this or that region as a Homeland.

\section{Area of the Homeland}

Because said above we must discuss the problem of localizing the Indo-European Homeland. Many scholars also suppose that the Eastern European localisation of the Indo-European homeland can be confirmed by the presence of very ancient contacts between the bearers of the proto-Indo-European and proto-Finno-Ugrian languages. However, analysis of the vocabulary testifies in favour of the diametrically opposite point of view. There is no actual evidence of such contacts: the earliest between people speaking these languages took place after the disintegration of the protoIndo-European language- between bearers of proto-Finno-Ugrian and one of the early Indo-Iranian dialects. Somewhat later came borrowings from the Tocharian tongues into Finno-Ugrian, but evidence about contacts is limited to these Tocharian and Aryan borrowings [20]. Therefore, some affinity of proto-Indo-European and proto-Uralic can be discussed from the position of the Nostratic theory only.

Analysis of Indo-European languages by T.V. Gamkrelidze and V.V. Ivanov $[8,9,21]$ revealed early Indo-European contacts with Semites, Kartvelians, and North Caucasians. In addition, the nature of the landscape, flora and fauna of the Indo-European homeland have been reconstructed. This has allowed them to place the Indo-European homeland in the area including Eastern
Anatolia, the Armenian Plateau, and Iranian Azerbaijan. The same regions are indicated by analysis of the lexicon, which allowed the Indo-European environment to be reconstructed. The East European theory is not able to explain the developed mountain lexicon in the PIE as well as inclusions from the Near Eastern languages. Therefore, this "Kurgan theory" can exist further only in case of appearance of linguistic works which would show that the reconstruction of mountain lexicon is erroneous, as are also erroneous the reconstructed language connections with the Near Eastern languages. Contrary to this, there are new works about PIE connections with Afro-Asian languages [22]. Against this background, archaeological models of the Eastern European Homeland cannot be discussed any more.

However, there is a problem of culture and economy of the IndoEuropeans reconstructed on the base of language analysis. The Indo-European economy was, above all, agricultural. In Eneolithic cultures of the south of Eastern Europe agriculture was absent. Actually, even cattle breeding were widespread weakly, and ideas about a horse-breeding economy are called recently in question [23].

It is necessary to emphasize that only cultures of the Pre-ceramic Neolithic in Northern Mesopotamia show strict correspondence to the linguistic reconstruction of the early Indo-European culture and economy (see $[8,9]$, and compare [7]). Cattle were already domesticated, but their part in the herd was insignificant. Goats and, especially, sheep formed its basis. The term 'sheep' even corresponded to the concept of 'the whole herd/flock'. The words for wheat and barley form part of common Indo-European terminology. Millet, rye and oat do not start to be cultivated until after the appearance of separate dialects. The first Indo-Europeans harvested using sickles; grain was not ground but pounded. Flax is known, but not in all dialects. Spinning, weaving and sewing were known. The common terminology of the potter is absent, but the terms for notions such as 'to pug', 'clay', 'to model' and 'pise wall' go back to the proto-Indo-European condition. There is a common term for designating a fence or fortification. There is also a common term for copper, but a unified terminology linking forging and metallurgical activity is wanting.

The all this terminology is fully reflected in realities of the Preceramic Neolithic sites. On all settlements of the 7th- 6th millennia $\mathrm{BC}$ the only kinds of domesticated cereals were barley and wheat; on some, flax is detected. Cereals were harvested by sickles with stone insets, and grain was pounded by pestles in mortars or on millstones.

Small copper objects show that there was knowledge of metal, but its processing by means of cold forging explains the absence of special terminology. Of domestic animal remains, the most part of bones belong to sheep and goats, and only 2-3 percent to cattle. The part of cattle and pigs in the herd increased later. There are no ceramic vessels, but clay was used for manufacturing small figurines and in building, including small defensive walls.

It is impossible to find another area with such conformities. If it were possible, it would be interesting to know about this. Either 
it would be interesting to know an argued opinion that basing on the Indo-European language it is possible to reconstruct another type of economy, for example horse-breading. By the way, horse is known in herd in the Southern Caucasus and Eastern Anatolia from the $5^{\text {th }}-4^{\text {th }}$ millennia BC (on the settlement of Alikemektepesi its part is 7.5 percent), which corresponds to its later appearance according to the linguistic reconstruction. In earlier settlements of Shulaveri-Shomutepe culture (Arukhlo and Tsopi, 6th -5th millennia $\mathrm{BC}$ ) bones of horse are known, but it is not excluded it was a wild horse [24].

In addition to this, it is necessary to remember that the idea about the Indo-European Homeland in Northern Mesopotamia was based initially on reconstruction of paleo landscape and evidences about language contacts with other Near Eastern languages. Therefore, this area is a single possibility to localize the Homeland.

\section{Indo-European Migrations}

Another part of the problem is ways of migrations of the IndoEuropeans to places of their historical residence. I shall touch upon the most general picture based on analyses of archaeological materials. However, analyzing these materials we are not able to say which language spoke people produced particular ceramic and metal artifacts. To establish language affiliation of any archaeological culture it is necessary to compare the most general processes reconstructed on both archaeological and linguistic base. If these processes coincide, we may suppose that they were identical processes and talk about correspondence of distribution of any cultural complex to distribution of any particular language. Thus, further we shall talk about a scheme of distribution of these or that cultural complexes and innovations as well as about their possible language attribution.

After formation of Neolithic cultures in the Near East and drastic population increase a permanent outflow of people from the area in different directions started. It was a basic reason of the IndoEuropeanization of the continent. However, we must remember that in the Near East different peoples lived, spoken Indo-European, Dene- Caucasian and other languages, and we cannot always talk about the Indo-European migrations.

It is an indisputable fact that people who brought Neolithic cultures to the Balkans (and then to Central Europe) came from the Near East. The presence of Indo-European river-names in Central Europe is, probably, evidence of migrations of Indo-Europeans on the very early stage of dialectal partitioning of their language. However, from this it does not follow that just these populations were a base for development of later European dialects. In my opinion, their separation from the main Indo-European core resulted in isolation and formation in the Balkans of Anatolian dialects. The following disintegration of Balkan Eneolithic cultures and movement of these tribes to Anatolia resulted in appearance in Anatolia of some Bronze Age cultures including Kuro- Araxian in the east, with the Balkan roots. Sometimes this process is used to show that the Indo-Europeans appeared in Anatolia from steppes of Eastern Europe through the Balkans. At this time, the steppe component really penetrated the Balkans. However, in Anatolia the former Balkan populations appeared [25-28], whose roots were initially in Anatolia. Nobody demonstrated movements of the steppe populations to Anatolia, though, probably, they were a trigger of this migration. These processes may be connected with coming of people spoken Anatolian dialects and start of separation of Hittite, Luwian and Palaic languages.

Permanent cultural influences from the Near East to the Caucasus do not need to be discussed. These influences were notable already in the Neolithic when on such settlement as Rakushechnii Yar traces of a cattle-breeding economy, which could be introduced only from the south, are reported. In the Eneolithic in steppe complexes such as Novodanilovo and lower layer of the settlement of Mikhailovka there are features of the Transcaucasian Eneolithic complexes such as Tekhut and Alikemektepesi. The brightest expression of these influences is Maikop culture influenced cultural developments in the Northern Caucasus and Eastern Europe. Therefore, these influences and migrations in the Eneolithic and the Early Bronze Age were rather long. Nevertheless, it is necessary to distinguish here the Indo-European and North Caucasian influences. Migrations of people spoken Paleobalkan dialects are also probable, which resulted in the appearance of Eastern European components in the Balkans.

All this described above corresponds to the presence in the Balkans of two pre-Greek layers of place-names: Anatolian and Paleobalkan $[8,29]$.

Greek migrations can be reconstructed too. They are visible in appearance in North-Western Anatolia of Cappadocian ware from the east and then Minian ware in the Balkans [30]. A sharp cultural break in Greece at the beginning of the Early Helladic III period may be probably connected with migrations of Achaean Greeks [31]. There are reasons to suppose that the Mycenaean Greeks settled in the vicinity before moving into Greece. As its subsequent close connections with the Mycenaeans indicate, this was Transylvania, whence objects comparable with Mycenaean ones occur from the Apa- Hajdusamson horizon [32]. People spoke in the future Dorian language settled during a long time in the north of the peninsula.

Migrations of Indo-Iranians can be traced back basing on the Near Eastern theory too. In this connection, an idea of LS Klein [33] about the Near Eastern roots of Catacomb culture is worth of attention, as well as connection of this culture with the Caucasus and catacombs of the Eastern Mediterranean. This corresponds to found by Trubachev [34] evidences of the Indo-Aryan presence in North Pontic area, and later presence of Mitannian Aryans in the Near East. Origins and development of the catacomb burial tradition is quite visible in North-Eastern Iran and south of Central Asia in such complexes as Parkhai and Sumbar starting from the late $5^{\text {th }}$ - early $4^{\text {th }}$ millennia BC (Figure 1 ). It is very important that the following Indo-Aryan invasion to India was connected just with cultures of this area. A number of cultures to the north of India (Tulkhar cemetery, Swata) demonstrate similarities in Iran and Balujistan, but any connections with steppe Eurasian cultures were absent. The last are a historiographical myth. Understanding this, 
one of supporters of this movement from the north A Parpola [35] formulated an idea of "Kulturkugel" when steppe cultures get to Bactria and Margiana, and further the Baktro-Margianan complex moves to the south, being now the bearer of Indo-Iranian languages obtained from northern newcomers. Artificiality of this approach is obvious, as well as its chronological discrepancy.

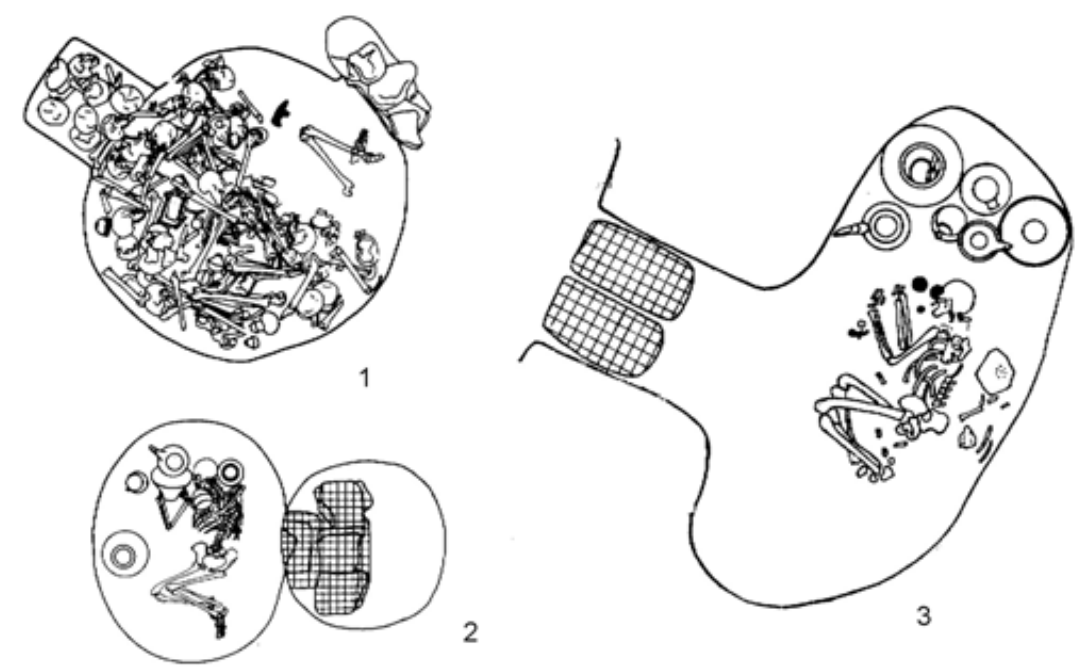

Figure 1: Catacomb burials of the Tulkhar [1,2] and Sumbar [3] cemeteries.

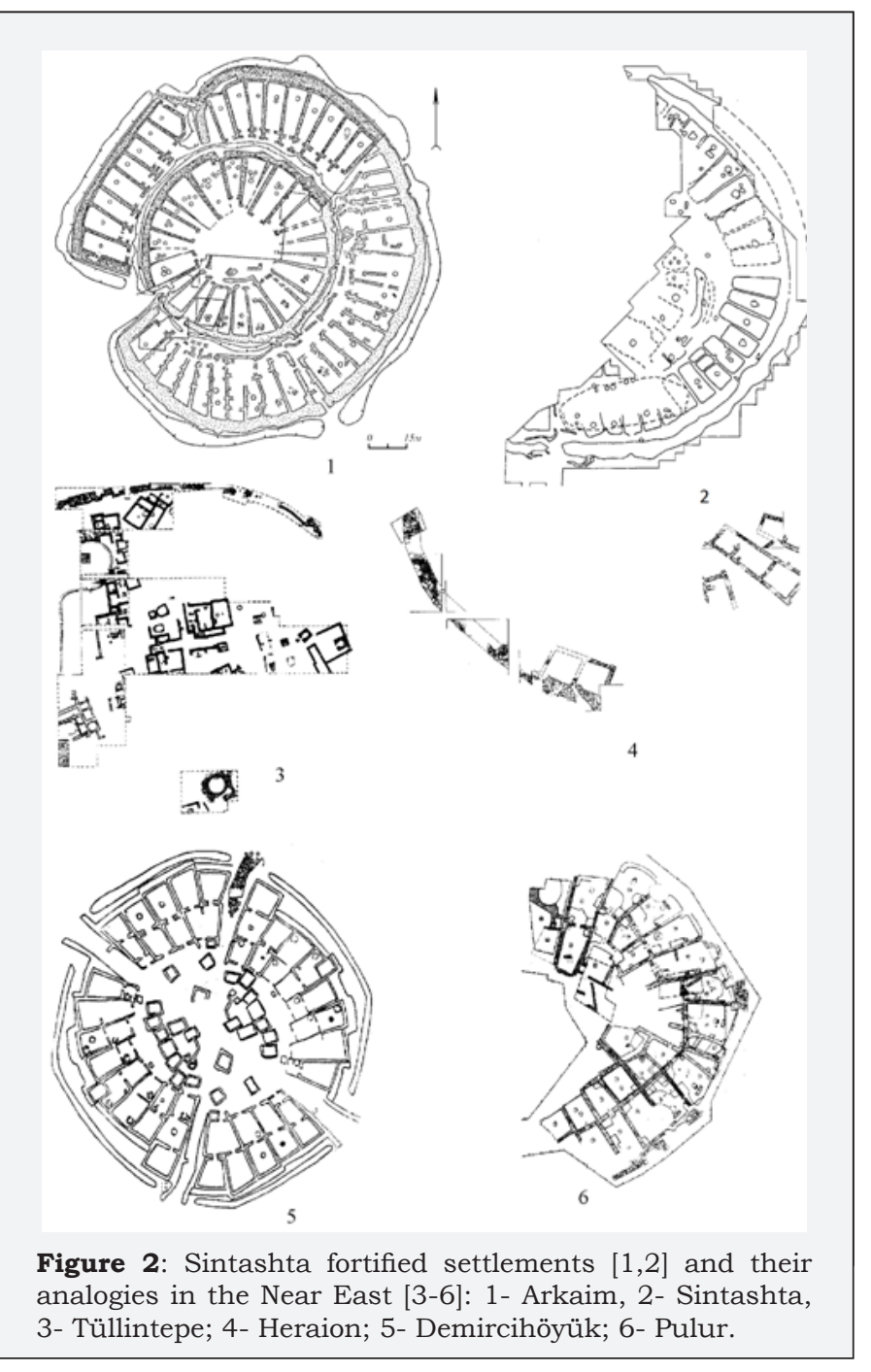

Moreover, the Bactro-Margianan archaeological complex (BMAK) had some connections with India but its penetrating there cannot be demonstrated. In my opinion, people left this complex spoke early Iranian dialects. VI Sarianidi [36] has demonstrated that the formation of this complex was caused by migrations from Syro-Anatolian area. In the 14th -13th centuries BC Grey Ware culture appeared in Western Iran and this tradition existed up to the Akhemenid period, which allows this tradition with Medes and Persians to be connected. The roots of the culture were in the area of the Bactro-Margianan archaeological complex. Thus, it is quite possible that the Iranian coming to Bactria and Margiana in the 18th century BC resulted in forcing out the Indo-Aryans and their movement to India.

Another Iranian group from Syro-Anatolian area penetrated the Southern Urals forming Sintashta culture. In this culture we can find parallels to the whole complex of material culture, metallurgical technologies, even to original microstructures of Sintashta slag. And, these features are interconnected and form an integral system.

The analogies in architecture are most important (Figure 2). Sintashta fortified settlements had round plan and usually two lines of fortifications. Dwellings within settlements were placed behind each line of fortifications, and were joined to the defensive wall at the end. Each longitudinal wall was common to two adjacent dwellings. This architectural tradition had no predecessors in steppe zone, but its development may be traced back to Near Eastern prototypes. A similar method of construction is named the "Anatolian settlement scheme". Its miscellaneous developments present on many settlements: Haçilar, Mersin, Pulur, KaratasSemayük, Aphrodisias, Heraion, Alişar, Troy, Tarsus, etc. [37]. In addition to this, similarity is observed not only in the general outline, but also in details: fireplaces near walls and in central parts of the dwellings, for example. 


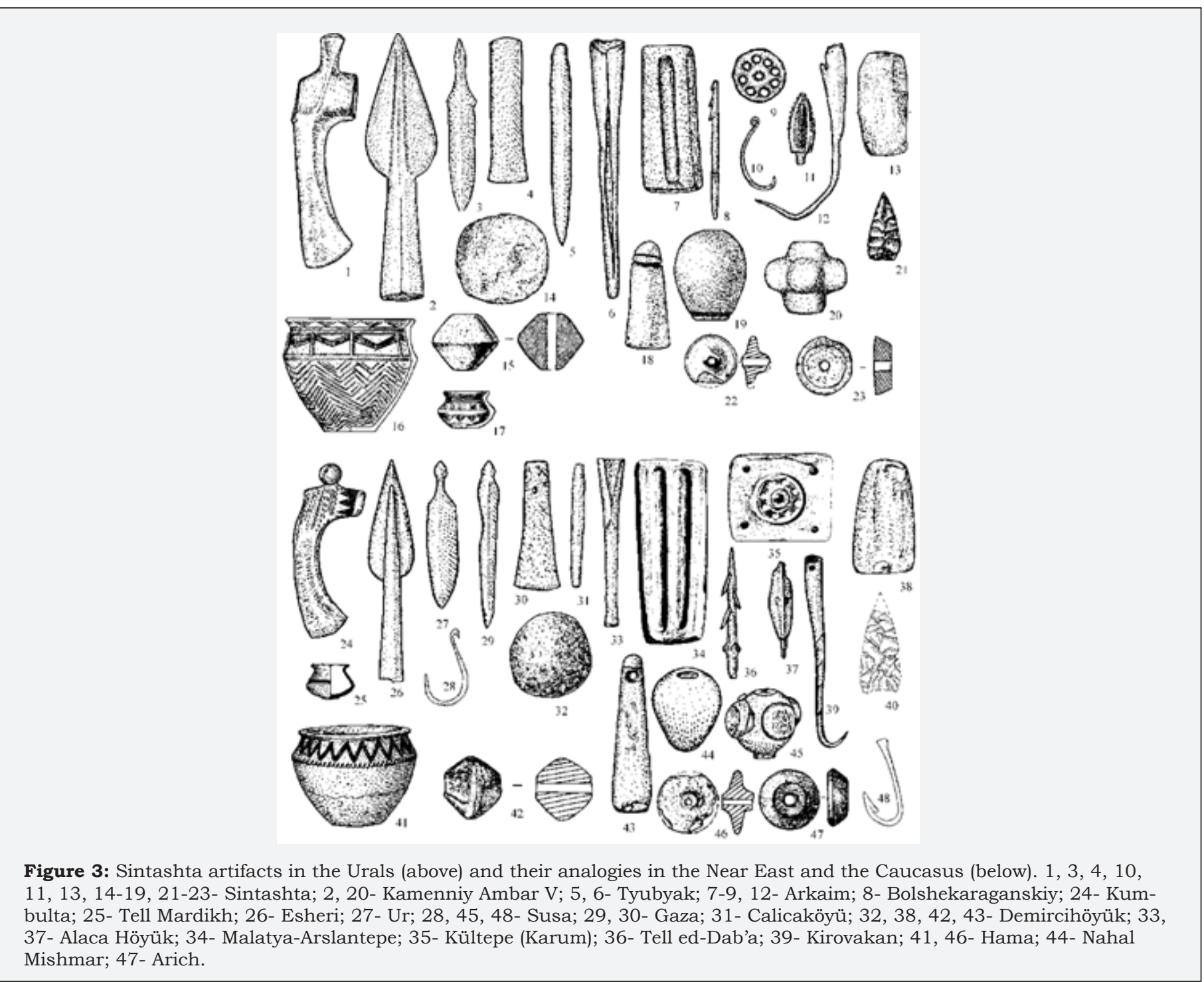

However, other artifacts have the same Caucasian and Near Eastern parallels: a set of metal and stone artifacts, some ceramic types (Figure 3). I do not think that it is possible to find another explanation to this conformity except for direct migrations. Metallurgy is most indicative [38]. It was based on smelting ores from ultrabasic rock, which was typical of Eastern Anatolia. The Sintashta tradition of alloying with arsenic minerals with nickel admixtures on the stage of ore smelting is typical of the Near East too. But it is also necessary to note that they are not separate parallels, they form a united complex: the type of ore bearing rock allowed smelt at temperature below $1300{ }^{\circ} \mathrm{C}$ that did possible the alloying with arsenic at a stage of ore smelting. To save arsenic in metal metallurgists used casting technologies very rarely, forge technologies at low temperatures dominated. These technologies caused morphological characteristics of tools and weapons. Smelting of oxidized ores (sometimes secondary sulfide ore could be added) in relatively small furnace demanded creation of deoxidizing atmosphere. It was possible by means of slow blasting from a well into the furnace (the most part of the Sintashta furnaces situated near wells) and generation, by such a way, of carbon monoxide. Here we see that all parts of metallurgical production not only were interconnected, but they were connected with Sintashta architecture. And, all of them separately had no predecessors in steppe Eurasia.

Extraction of silver from lead ores by the method of cupellation was known in both Anatolian and Sintashta sites. In Eastern Europe this technology is not revealed for this period.

Basing on everything said above, we might conclude that the rise of Sintashta culture was connected with the appearance in the north of the Near Eastern cultural complex in a pure, almost not transformed shape.

In principle, it would be possible to stop here, because many Late Bronze Age cultures from the Dnieper to Irtysh and Central Asia formed on the Sintashta base; that allows us to solve the problem of Iranian migrations to the north.

However, the following culture of the Scythians and Sarmatians did not form on this base. In spite of the fact that this is a common opinion and just this postulated connection of steppe cultures of 
the Bronze Age with cultures of the Early Iron Age was a basis for the identification of the Bronze Age cultures with the Indo-Iranians, the real situation is different. At the end of the Final Bronze Age, a sharp deterioration of ecological situation took place. In the whole steppe zone from the Don to the foothills of Altai the quantity of sites sharply decreases. For this period, a very limited number of inexpressive burials is known which have not something in common with the subsequent culture of the Scythians and Sarmatians. Its formation was connected with cultures of Karasuk and Irmen' type in Central Asia, and as it has been demonstrated by NL Chlenova $[39,40]$ the cultures of this type had the Near Eastern roots. In recent years, this point of view finds more and more confirmation in archaeological materials of this period. Impulses from the East are visible at formation of the Early Iron Age culture at two stages: during the Final Bronze Age and, mostly, at the beginning of the Early Iron Age.

At last, the most disputable part of the theory of Gamkrelidze and Ivanov is migration of people speaking ancient European dialects: the Celts, Italics, Balts, Slavs, and Germans. The migration from the Near East around the Caspian Sea to Europe. Archaeological expression of this migration is movement of SeimaTurbino and Fyodorovo/Andronovo people. There is no question about their westwards migrations from the Altai [41]. The question of their origins is more complicated. In my opinion metallurgical innovations brought by these cultures (smelting of copper sulfides, tin-alloys, new casting technologies and type of weapons and tools) had nor roots in the north. For the first time they appeared in the Near East and were distributed in Northern Eurasia and then in Europe.

It is necessary to add one more explanation. Very often at the description of Indo-European migrations in the steppe zone "Andronovo culture" is used. In different texts we can read about the Andronovo migrations to the south that leads to the appearance there of the Iranians and Indo-Aryans. Sometimes the east groups of Andronovo people are used to explain presence of the Tocharians in Central Asia, though the western Andronovo people are considered as the Indo-Iranians. All this causes serious questions from the point of view of chronology of the dialectal partitioning of IndoEuropean languages. More precisely, this does not correspond to this chronology at all. But, if we even ignore these problems, we should discuss the Andronovo culture more realistic. Because of popularity of this term, my following thesis will seem paradoxical though it will not surprise people who directly study this culture. A part of them will agree with this thesis, another part will be disagree, but this will be based on the attitude to that on what base it is possible to unite archaeological materials into any culture. This thesis is follows: the Andronovo culture did not exist. If not to consider some small cultural formations of this period, the culture consists of two different parts. The first is Alakul culture created on the Sintashta base. The second is Fyodorovo culture. Earlier there were ideas that this culture was formed in the middle of 2 nd millennium BC on the Alakul base. However, another point of view always existed, and it now dominates: the Fyodorovo culture was created irrespective of
Alakul, and, within Northern Eurasia, it appeared first in the east, and its bearers began to move to the west. Interaction of these two cultures led to formation of some similar features that allowed speaking about some Andronovo unity. However, in pure form these cultures are non-comparable. Therefore, the use of Andronovo culture for demonstration of the processes of the eastward and southward Indo-European migrations is based on incorrect understanding of processes of cultural genesis in Northern Eurasia. At the same time, this interaction of the moving from the east Fyodorovo culture with Alakul culture of the steppe zone is well coordinated with Gamkrelidze and Ivanov's reconstruction, who on the base of the analysis of language consider that in the course of migrations across Northern Eurasia ancient Europeans had intensive contacts with bearers of an early Iranian dialect [21].

It is a very indicative example as it is easy to find to the system of Indo-European migrations reconstructed by the abovenamed authors not only concrete archaeological equivalents, but we often find similarities at a level of details. Conformity of the linguistic model and the archaeological model allows us to say that they describe identical processes. There are, of course, also some distinctions between these two systems. A part of these distinctions may be explained by mistakes of the linguistic system, another part- by mistakes in the archaeological reconstruction. Some discrepancies have been caused by our simplification of these processes and any difficult nuances, which are concealed from us yet. Nevertheless, these discrepancies will be overcome during the following work.

\section{Conclusion}

Thus, despite unpopularity of the idea about the Near Eastern connections of cultures in Northern Eurasia and weak study of these connections, their number is large, and in the future this information will increase. It is possible to contest individual facts and to prove that this or that feature could have autochthonous origins. However, it is already impossible to deny the abundance of these connections today. And essentially, it is well coordinated with the linguistic theory of the origins of Indo-Europeans.

Contrary to this, the "northern" component in the south is completely lacking. Supporters of this theory must answer only two simple questions: WHERE? and WHAT EXACTLY? The same questions can be also asked to linguists who try to speak about the Indo-European Homeland in the north. I do not think that we will wait until the detailed developed answers. It is a characteristic property of dominating errors. Statements in their favour may not be supported by a reasonable argumentation. They are perceived with approval and understanding even without it. Moreover, all that it was possible to throw on scales of the theory about the steppe Homeland of the Indo-Europeans is already thrown. And, there is not enough argumentation, or this argumentation is based on false evidences.

One more aspect of the problem is connected with it. Some authors, who believe that Indo-European Homeland was in Anatolia, reject a migratory way of the Indo-European languages distribution 
$[13,42]$. They believe that languages could be distributed by means of contacts. Similarly, many archeologists think that cultural borrowings were a way of appearance of cultural features from distant areas. Nevertheless, we do not know historical examples of such a way for new languages. It is also impossible for culture. We may admit transfer of some individual features. However, as a rule, we deal with system transformations. It is especially indicative in metallurgy, which cannot be borrowed through areas where ore deposits are lacking. Therefore archeologists should get accustomed to the idea of long-distance migrations and understand that they took place not only in the Early Iron Age and the Middle Ages (what is well reflected in written sources), but also much more earlier.

Thus, today we have no alternative to the Indo-European migrations from the Near East. And now the most interesting stage in research of this problem begins: stage of detailed study and statement of more complex and interesting problems.

\section{Acknowledgement}

I am very grateful to the reviewers of my first book on this subject published in 1999 [43]. First, it is Professor of the University of California (LA) Vyacheslav Ivanov, who helped me to gain confidence and with many important advices. Another scholar who should be mentioned is Professor Victor Sarianidi from the Institute of Archaeology (Moscow). He jokingly quoted V Lenin: "The circle of these revolutionaries is narrow. They are terribly far away from the people". Unfortunately, they both left us last years. And this article is devoted to their memory. The third person who supported me in this early period is Professor Mikhail Kosarev from the Institute of Archaeology (Moscow).

\section{References}

1. Childe V (1958) The prehistory of European society. [How and why the prehistoric barbarian societies of Europe behaved in a distinctively European way. Penguin Books, Harmondsworth, London, UK.

2. Piggott S (1965) Ancient Europe from the beginnings of agriculture to classical antiquity. University Press, Edinbourgh, UK.

3. Gimbutas M (1970) Proto-Indo-European culture: The Kurgan culture during the fifth, fourth, and third millennia B.C. In: Cardona G, Hoenigswald H, Senn A (Eds.), Indo-European and Indo-Europeans, University of Pennsylvania Press, Philadelphia, USA, pp. 155-197.

4. Gimbutas M (1994) Das ende alteuropas. Der einfall von steppennomaden aus südrußland und die indogermanisierung mitteleuropas. Institut für Sprachwissenschaft, Innsbruck, Austria.

5. Mallory J (1989) In search of the Indo-Europeans. Language, Archaeology and Myth. Thames \& Hudson, London, UK.

6. Anthony D (2007) The horse, the wheel, and language. How Bronze Age riders from the Eurasian steppes shaped the modern world. Princeton University Press, Princeton, USA.

7. Grigoriev S (2002) Ancient Indo-Europeans. Rifei, Chelyabinsk, Russia.

8. Gamkrelidze T, Ivanov V (1984) Indoevropeiskii yazik I indoevropeicy [Indo-European language and the Indo-Europeans] Tbilisi University Press, Tbilisi, Georgia.

9. Gamkrelidze T, Ivanov V (1995) Indo-European and the Indo-Europeans: A reconstruction and historical analysis of a proto-language and proto-culture. Mouton de Gruyter, Berlin- New York, Germany.
10. Krahe H (1963) Die Struktur der alteuropäischen hydronymie. Akademie der wissenschaft und der Literatur, Wiesbaden, Germany.

11. Schmidt W (1977) Baltische wassernamen und das vorgeschichtliche Europe. Indogermanische Vorschungen 77: 1-18.

12. Renfrew C (1987) Archaeology and language. Pimlico, London, UK.

13. Safronov V (1989) Indoevropeiskie prarodiny [Indo-European Homelands]. Volgo-Vyatka Publishing, Gorkii, USSR.

14. Merpert N (1988) Ob etnokulturnoi situacii IV-III tysyacheletii do NE $\mathrm{V}$ Cirkumpontiiskoi zone [On the ethno-cultural situation of the $4^{\text {th }}-3^{\text {rd }}$ millennia BC in the Circumpontic zone]. In: Bongard-Levin G, Ardzinba V (Eds.), Drevnii Vostok: etnokulturnie svyazi [Ancient East: Ethno-cultural ties], Nauka, Moscow, Russia, pp. 7-36.

15. Chernikh E (1988) Cirkumpontiiskaya provinciya I indoevropeicy [Circumpontic province and the Indo-Europeans]. In: Bongard-Levin G, Ardzinba V (Eds.), Drevnii Vostok: etnokulturnie svyazi [Ancient East: Ethno-cultural ties], Nauka, Moscow, Russia, pp. 37-57.

16. Mallory J (1996) The Indo-European Homeland Problem: a Matter of Time. In: Jones-Bley K, Huld M (Eds.), The Indo-Europeanization of Northern Europe, Institute for the Study of Man, Washington DC, USA, pp. 1-22.

17. Gamkrelidze T, Ivanov V (1980) Drevhyaya Perednyaya Aziya I indoevropeiskaya problema. Vremennye I arealnye kharakteristiki obsheindoevropeiskogo yazyka po lingvisticheskim I kulturno-istoricheskim dannym [Ancient Near East and the Indo-European problem. The temporal and areal characteristics of the Common Indo-European language in terms of linguistic and cultural-historical data]. Bulletin of ancient history 3 : 3-27.

18. Gray R, Atkinson Q (2003) Language-tree divergence times support the Anatolian theory of Indo-European origin. Nature 426: 435-439.

19. Bouckaert R, Lemey P, Dunn M, Greenhill S, Alekseyenko A, et al. (2012) Mapping the origins and expansion of the Indo-European language family. Science 337(6097): 957-960.

20. Napolskikh V (1997) Vvedenie v istoricheskuyu uralistiku [Introduction to historical Uralistics], Udmurt Institute of History, Language and Literature, Izhevsk, Russia.

21. Gamkrelidze T, Ivanov V (1981) Migracii plemen-nositelei indoevropeiskikh yazikov s pervonachalnoi territorii rasseleniya na Blizhmen Vostoke $\mathrm{v}$ istoricheskie mesta ikh obitaniya $\mathrm{v}$ Evrazii [Migrations of tribes-bearers of Indo-European dialects from the original territory in the Near East to their historical habitats in Eurasia]. Bulletin of ancient history 2: 11-33.

22. Blažek V (2013) Indo-European zoonyms in Afroasiatic perspective. Journal of Language Relationship 9(2013): 37-54.

23. Levine M (1999) The origins of horse husbandry on the Eurasian steppe. In: Levine M., Rassamakin Yu, Kislenko A, Tatarintseva N (Eds.), Late prehistoric exploitation of the Eurasian steppe, McDonald Institute for Archaeological Research, Cambridge, UK, pp. 5-58.

24. Eneolith of the USSR (1982) Nauka, Moskau, Russia.

25. Parzinger H (1993) Studien zur Chronologie und kulturgeschichte der jungstein-, kupfer- und frühbronzezeit zwischen karpaten und mittleren Taurus. Philipp von Zabern, Mainz, Germany.

26. Mellaart J (1971) Anatolia c. 4000-2300 BC. In: Edwards I, Gadd C, Hammond N (Eds.), The Cambridge Ancient History, V. I, P. 2, University Press, Cambridge, UK, pp. 363-416.

27. Özdogan M (1991) Eastern Thrace before the Beginning of Troy I- an Archaeological Dilemma. In: Lichardus J (Ed.), Die Kupferzeit als historische Epoche; Symposium Saarbrucken und Otrenhausen, I, Rufolf Habelt, Bonn, Germany 1: 217-225.

28. Yakar J (1991) Prehistoric Anatolia. The neolithic transformation and the early chalcolithic period. Tell Aviv University Press, Tel Aviv, Israel. 
29. Titov V (1970) K voprosu o sootnoshenii etnolingvisticheskikh sloyov I kulturno-istoricheskukh obshnostei na yuge Balkanskogo poluostrova [On the issue of correlation of ethno-linguistic strata and cultural-historical communities in the south of the Balkan Peninsula]. Kratkiye soobshcheniya Instituta arkheologii- KSIA (Brief Communications of the Institute of Archaeology) 123: 32-41.

30. Mellaart J (1971) Anatolia c. 2300-1750 BC. In: Edwards IES, Gadd CJ, Hammond NGL (Eds.), The Cambridge Ancient History, V. I, P. 2, Cambridge University Press, Cambridge, UK, pp. 681-706.

31. Caskey J (1971) Greece, Crete, and the Aegean Islands in the Early Bronze Age. In: Edwards IES, Gadd CJ, Hammond NGL (Eds.), The Cambridge Ancient History, V. I, P. 2, Cambridge University Press, Cambridge, UK, pp. 771-807.

32. Lichardus J, Vladar J (1996) Karpatenbecken - Sintasta - Mykene. Ein Beitrag zur Definition der Bronzezeit als historischer Epoche. Slovenska Archeologia XLIV (1): 25-93.

33. Klein L (1970) K proverke osnovanii gipotezy o geneticheskoi svyazi yamnoi I katakombnoi kultur [To verifying the foundations of the hypothesis of a genetic connection between the pit-grave and catacomb cultures]. Soviet Archaeology 1: 49-57.

34. Trubachev (1999) Indoarica v Severnom Prichernomorye [Indoarica in the Northern Black Sea Region]. Nauka, Moscow, Russia.
35. Parpola A (1988) The coming of the Aryans to Iran and India and the cultural and ethnic identity of the Dasas. Studia Orientalia 64(1988): 195-302.

36. Sarianidi V (1998) Margiana and protozoroastrism. Kapon, Athens, Greece.

37. Korfmann M (1983) Demircihüyük. Die Ergebnisse der Ausgrabungen 1975-1978. I. Architektur, Stratigraphie und Befunde. Philipp von Zabern, Meinz, Germany.

38. Grigoriev S (2015) Metallurgical Production in Northern Eurasia in the Bronze Age. Archaeopress, Oxford, UK.

39. Chlenova N (1972) Khronologiya kinzhalov karasukskoi epokhi [Chronology of sites of the Karasuk epoch]. Nauka, Moscow, Russia.

40. Chlenova N (1974) Karasuk kinzhaly [Karasuk daggers]. Nauka, Moscow, Russia.

41. Chernikh E, Kuzminikh S (1989) Drevnyaya metallurgiya Severnoi Evrazii [Ancient metallurgy in Northern Eurasia]. Nauka, Moscow, Russia.

42. Sherratt A, Sherratt E (1988) The archaeology of Indo-European: An alternative view. Antiquity 62(236): 584-595.

43. Grigoriev S (1999) Drevnie indoevropeicy. Opyt istoricheskoi rekonstrukcii [Ancient Indo-Europeans. Attempt of historical reconstruction]. Rifei, Chelyabinsk, Russia. 